\title{
STUDENTS' ATTITUDE TOWARD THE IMPLEMENTATION OF ROLE-PLAYING ACTIVITY IN ENGLISH FOR BUSINESS CLASS AT MANAGEMENT DEPARTMENT
}

\author{
Fuad Abdul Baqi ${ }^{1}$ \\ ${ }^{1}$ Unversitas Bina Bangsa Serang \\ Fuadbaqi80@gmail.com
}

\begin{abstract}
ABSTRAK
Penelitian ini tentang sikap mahasiswa terhadap pelaksanaan kegiatan role-playing dalam bahasa Inggris untuk kelas bisnis Jurusan Manajemen. Bahasa Inggris untuk Bisnis merupakan mata kuliah wajib Jurusan Manajemen di Universitas Bina Bangsa. Penelitian ini bertujuan untuk mendeskripsikan sikap siswa terhadap pelaksanaan kegiatan bermain peran di kelas. Kegiatan bermain peran adalah teknik yang sangat efektif dan kuat yang dapat membantu siswa meningkatkan kreativitas dan kemampuan mereka dalam berbicara, dapat menciptakan lingkungan belajar yang menyenangkan juga, dan kelas menjadi lebih interaktif dan berorientasi pada mahasiswa. Penelitian ini diikuti oleh 40 mahasiswa program studi manajemen yang mengambil mata kuliah English for Business. Data dikumpulkan melalui kuesioner, wawancara dan observasi yang kemudian dianalisis dan ditabulasi. Hasil penelitian ini menunjukkan bahwa sebaynayak 80\% mahasiswa memiliki sikap positif terhadap kegiatan bermain peran selama proses pembelajaran. Menyadari peran mereka dalam situasi tertentu berdasarkan topik yang dipelajari di kelas dan memainkan peran membuat mereka lebih mudah untuk berlatih berbicara bahasa Inggris dan meningkatkan kemampuan bahasa Inggris mereka. Siswa juga antusias untuk belajar bahasa Inggris karena itu menyenangkan bagi mereka.
\end{abstract}

Kata kunci: Sikap Siswa, Role playing; Bahasa Inggris untuk bisnis

\begin{abstract}
This research is about the students' attitude toward the implementation of role-playing activities in English for business class of Management Department. English for Business is a compulsory subject for Management Department at Bina Bangsa University. The aim of this research was to describe students' attitudes towards the implementation of role-playing activities in the classroom. Role-playing activities is a very effective and powerful technique that can help students enhance their creativity and ability at speaking, it can create a favorable learning environment as well, and classes became more interactive and studentoriented. 40 students of the management study program who took English for Business subject took a part in this research. Data were collected through questionnaires, interviews and observations which were then analyzed and tabulated. The results of this study showed that $80 \%$ of students had a positive attitude towards role playing activities during learning process. Recognizing their role in certain situations based on the topics studied in the class and playing the role made them easier to practice speaking English and enhance their English ability. Students were enthusiastic as well to learn English because it was fun for them. students are contented with their performance in role-playing activities.
\end{abstract}

Keywords: Student'Attitude, Role playing; English for business 
In the globalization era, English has become a necessity for people around the world to make interaction one another for achieving their purposes in any aspect of life, such as business, politics, social and culture, education, etc. For that reason, the necessity of English proficiency has become a priority and crucial thing to be mastered. Today's technological developments have affected the teaching of English. Instead of technology, scientific and economic developments require the use of English as a media of communication between experts around the world. This is due to the need for English as a communication tool. When someone is able to speak a language, it means he can make a conversation quite competently (Harmer, 2001). In doing so, students should master English in their respective fields. It attracts course designers to convert general English usage to English for specific purposes. The English for specific purpose refers to a language learning approach that guides learners to fulfill the purpose of why they need to learn the target language.

The traditional ESP teaching commonly focuses on conveying language information through reading comprehension, writing, vocabulary and grammar exercises ignoring the need to integrate it with skills. However, they believe that interactive teamwork, critical reading and writing, communication skills, negotiation, presentation are some of the soft skills and essential for the academic environment and future work. Foreign languages have not been studied for their own sake but as a tool for social and economic contact and for brainstorming ideas.

English has been taught in schools and is a compulsory subject for middle and high schools. Educators are dealing with challenges in teaching English because English is not implemented for daily conversation. Teaching activities carried out by the teacher will measure by teaching techniques and perceptions of these techniques. There are various techniques that can be employed to teach English, namely playing games, discussions, role-playing and presentations. Regarding the need for English as a specific purpose, several private universities in Indonesia include English in their curriculum as a compulsory subject to study. Students from several study programs will learn English according to their needs. It also applies at Bina Bangsa University in which second and third semester students of Management Study Program are obliged to take English for business to meet their English needs. The materials provided are practical, It means that students must practice speaking English by performing several roles. This is why most of them use role-playing activities as an effective technique in teaching students. 
In an English for Business class, a role-playing is performed when students take part of a particular person; a manager, a shop assistant etc. They act out the conversation. They do without a script, namely they do not prepare a script but they have prepared ideas. That is, role play has a number of possibilities for communication practice. Role play requires students to practice speaking English before they show off in real situations. In addition, students also learn in imaginary situations which are designed as real situations to enhance their English ability. This situation will lead students to implement English in real life.

The researcher can define that role-playing is an appropriate technique to support students' creativity in enhancing their ability in English. The students can freely chose the role they like to take a part, it leads them to be more enthusiastic in joining the play, practicing speaking English is enabling them to reduce their anxiety and it can improve their vocabulary mastery in business terms so that their speaking fluency looks more active and attractive.

The previous research had conducted by (Krebt, 2017), the research addresses the issue of role play in the college audio-visual class, its purpose is to suggest that the application of role plays could increase students' intercultural awareness and help them develop overall communicative competence.

The next similar research was conducted by Kumaran (2017), the research aims at finding out if role-play is beneficial in encouraging Malaysian secondary school students to speak in English. It involves students' reaction to the implementation of role-play and teachers' perception on the use of role-play as a speaking class activity in Malaysian classrooms. The rationale for performing this study is to give useful information and understanding to readers on the use of role-play activities in English language classrooms, the results suggest that students enjoy carrying out role-play activities and it pushes them to speak in English to a certain extent.

This research was conducted to describe Students' Attitude toward the Implementation of Role-Playing Activity in English for Business Class and what the urgency of it is. Because role play has been implemented in the classroom, it is hoped that students can acquire basic knowledge of English and help their academic life. However, it is important to know what students expect from it? What do they think about role-playing in English learning? Since English teaching is now student-centered, it is important to know their perceptions of the language they have learned in the class.

\section{Attitude}


Attitude is a positive, negative, or mixed evaluation of an object that is expressed at a cert ain level of intensity. It is an expression of favorable or unfavorable evaluation of a person, place, thing, or event. It is a fundamental determinant of our perceptions and actions regarding all aspects of our social environment. Attitudes contain a complex organization of evaluative, feelings, beliefs, and tendencies towards specific actions, how much we like or dislike something that decide our behavior towards that thing. We tend to approach, seek out, or be associated with things we like; we avoid, shun, decline or reject things we do not like (Iskandar \& Saragih, 2018).

Attitude has three main components (Perloff, 2017), namely:

1. Beliefs (beliefs), ideas, and concepts on an object.

2. Emotional life or evaluation of objects.

3. Tendency to act.

These three components together form a complete attitude (total attitude) and are influenced by knowledge, thoughts, beliefs and emotions. Attitude has several levels, including:

a. Receiving, at this level the individual wants to pay attention to the stimulus provided in the form of a particular object or information.

b. Responding, at this level the individual will give an answer when asked about a particular object and complete the assigned task. Individual effort for answering and completing the task given is an indicator that the individual has accepted the idea regardless of right or wrong efforts made by the individual.

c. Appreciating (valuing), at this level the individual is able to invite other people to work on or discuss a problem, meaning that the individual already has a positive attitude towards a certain object.

d. Responsible, at this level the individual is able to take responsibility and is ready to accept the risk of something he has chosen. This level is the highest level of attitude for someone to accept a new object or idea.

Attitudes can be categorized into three thought orientations (Iskandar \& Saragih, 2018), namely:

a. Oriented in response

This orientation was represented by experts such as Louis Thurstone, Rensis Likert and Charles Osgood. In their view, attitude is a form or feeling reaction. A more operational attitude towards an object (favorable or unfavorable)

b. Oriented to response readiness 
This orientation was represented by experts such as Chave, Bogardus, LaPierre, Mead, and Allport. Their conceptions were more complex. According to this orientation view, attitude is the readiness to react to objects in certain ways.

c. Traversing the triadic scheme

According to this orientation view, attitude is a constellation of cognitive, affective, and conative components that interact competitively in understanding, feeling, and behaving towards something. Attitudes are defined as certain regularities in terms of feelings (affection), thoughts (cognition) and predisposition of actions (konasi) a person to an aspect of the surrounding environment.

Based on opinion above, it can be concluded that attitude is a condition in which humans move to act or do something in response to situations or conditions of objects in their surroundings.

\section{Role-Playing}

Character in role playing is a concept that refers to the story, it is considered to be alive, so the process of creation and formation is not limited to visual strength, there are other formers that are important to construct, including identity, existence, and reality. As part of the form of simulated representation, a character is a character concept that is constructed, manipulated, and reproduced. The depiction of the quality of its manifestation involves the concept of shaping personality / characterization (archetypes), events (narrative), space and time (simulacrum).

Role-playing is acting according to predetermined roles for certain purposes such as reviving the historical atmosphere, for example re-expressing the struggles of heroes for independence, or expressing possible circumstances to come (Zagal \& Deterding, 2019). Grande-de-Prado et al. States role-playing "is a way of mastery of learning materials through developing the imagination and appreciation of students". The development of imagination and appreciation is carried out by students by playing them as living or inanimate figures. This game is generally done by more than one person, this depends on what is being played (Grande-dePrado et al., 2020).

Moreover Moreno defines role-playing is an activity in the learning process that students do not need to worry about, because this role play activity will create a real life atmosphere (Moreno-Guerrero et al., 2020). This activity is different from drama, the duration is very short. The teacher only provides short scenarios and students feel free to change or improve situations and characters. Students can develop their creativity as Gordon emphasizes 
that role-playing provides students the opportunity to be creative and allows them to undergo a time of practice which has an impact on reducing their anxiety (Gordon et al., 2017). In addition, in carrying out role play to educate students, teachers have important roles and responsibilities so that the teaching and learning process runs well. Harmer (2001) points out three different roles that teachers need to play so that students speak fluently. The first role is as a whisper. The second role is as a participant, and the last role is as a provider of feedback (Harmer, 2001).

Learning with role-playing is a way of mastery of learning materials through developing students' imagination and appreciation. The development of imagination and appreciation is carried out by students by playing them as living or inanimate objects. This method involves a lot of students and makes students happy to learn and this method has added value, namely: a) it can guarantee the participation of all students and provides the same opportunity to show their ability to work together to succeed, and b) games are a pleasant experience for students (Kustiarini \& Prasetyo, 2018).

From the definition above the researcher can conclude that role-playing is a suitable technique that can enhance students' creativity in improving their ability in English actively. The students also can willingly select the role they like to take a part, it leads them to be more active and motivated in joining the play, rehearsing repeatedly is enabling them to lessen their anxiety and it can increase their vocabulary mastery as well in business terms so that their speaking fluency looks more active, creative and attractive.

The researcher strongly believes that role-playing provides the opportunity to develop speaking and communication skills. Through practicing new vocabulary and structure have been working on. Practicing speech patterns such as making proposal, negotiating, agreeing or disagreeing, are very powerful way for them to build their confidence to speak English more actively. In other words, role-playing is a simulation exercise where students take on assumed roles in order to act out a scenario in a contrived setting. The students can act out the assigned roles in order to explore the scenario, they practice to communicate, negotiate, debate, etc.

Ultimately, the researcher sums up that Role play is very powerful and effective to be implemented in English for Business class. Because it is more focused on student-oriented learning, content-based approach, interactive learning, communicative approach, and constructivist teaching.

\section{Steps of Role-Playing Learning Method}

Samalot-Rivera (2014) suggested the stages of role-playing learning include:

1. Warm up the atmosphere and motivate students. 
Warming the atmosphere of the group including delivering students to learning problems that need to be studied. This can be conducted by identifying problems, explaining problems, interpreting stories and exploring issues, and explaining the role to be played.

This stage is more intended to stimulate students to be interested in the problem because this stage is critical in role playing and most determining success. Role playing will be successful if students take interest and pay attention to the problems posed by the teacher.

2. Choose a role

Choosing a role in learning, at this stage students and teachers describe various characters, what they like, how they feel, and what they have to do, then students are given the opportunity to voluntarily become actors.

3. Arrange the stages of the role

Developing new stages, at this stage the actors outline the scene to be played. In this case, there is no need for a special dialogue because students are required to act and speak spontaneously.

4. Setting up observers

Preparing the observer, the observer should be well prepared and involved in the story that will be played so that all students can experience and live the role played and actively discuss it.

5. Cast

At this stage the students began to act spontaneously, according to their respective roles. The role can stop when the students have had enough, and what they should have been trying to do. There are times when students are so engrossed in role playing that they unwittingly have taken too long. In this case the teacher needs to assess when the role playing is stopped.

6. Discussion and evaluation

Discussions are easy to initiate if the actors and observers are involved in role playing, both emotionally and intellectually. By asking a question, students will immediately be provoked for discussion.

\section{Re-role}

Re-role, carried out based on the results of evaluation and discussion of alternative roles. There may be a change in character roles required. These changes allow for new developments in problem-solving efforts. Any change in roles will affect other roles.

8. Discussion and evaluation phase two

Stage two discussion and evaluation, discussion and evaluation at this stage is the same as in stage six, only intended to analyze the results of the re-enactment, and the problem solving at this stage may be clearer. 
9. Share experiences and draw conclusions

At this stage, students are supposed to share their life experiences in dealing with parents, teachers, and friends and so on. All experiences of learners can be expressed or emerge spontaneously.

\section{METHOD}

This is a qualitative research. The purpose of this research is to identify students' attitudes towards the activities of role-playing in the class and how role-playing techniques are applied. The researchers used a questionnaire in the form of a Likert Scale and interviews to obtain data. The data is then analyzed using descriptive analysis. There were 40 students who participated in this study. The questionnaire consisted of 20 statements about their attitudes towards role-playing activities.

\section{RESULT AND DISCUSSION}

Students are assigned to carry out role-playing activities in connection with business activities in public places, company or business hub. They should act them out actively, they should practice how to interview another for possible employment, and they also should practice how to negotiate with another team to come to final terms for a contract for services or product, In addition, they also should be professional to present a product to a group of other students to purchase. This material is a part of the Business English course they must complete. Based those activities, the researcher tries to figure out and identify students' attitudes towards the role-playing activities they have carried out in the classroom. The research findings are described in the following paragraphs.

\section{a. Students' Attitude}

The results of the questionnaire indicated that the most students enjoyed learning English through role-playing. Respondents (80\%) "strongly agree" and "agree". They agree that learning English through role-playing is very interesting, and they perceive that such activities are much more fun and enjoyable. Because students have to prepare and arrange for their best performance in role-playing, they find it demanding to prepare. The students consider that these are challenging activities, eventually they are strongly motivated to learn English. This can be viewed from the results of the questionnaire where 32 respondents or $80 \%$ of the total respondents responded "strongly agree" and "agree". This is also confirmed by the results of the questionnaire. Student A responded whether he was motivated or not when learning English by using role play techniques. The response is as follows: 
Prosiding The 1st National Conference on Applied Business, Education, \& Technology (NCABET)"

Unversitas Bina Bangsa 2021

DOI Article : 10.46306/ncabet.v1i1.34

"I am strongly motivated, and very excited about learning English, and am really enjoying joining such activities" (S-1).

The other student response:

"Yes, because after I did it I felt excited and stimulated to memorize English vocabulary so that I will not feel complicated again during these activities "( $S-2)$.

Role playing implements different communicative techni ques and develops fluency language, promotes classroom interaction and increases motivation. Peer interaction has a variety of motivational and social benefits. These include: interacting with peers is more interesting than listening to lectures, improving communication skills, increasing selfawareness and also providing opportunities to form relationships. Role playing can be used effectively in the classroom to motivate and engage students, improve current teaching strategies, provide real-world scenarios to help students learn, learn skills used in the real world situations (negotiation, debate, teamwork, cooperation, persuasion), provide opportunities for critical observation of peers.

Role-play is very critical in a communicative approach because it provides opportunities for students to practice speaking or communicating in various social contexts and different social roles. A Role-play is a very flexible learning activity, which has a wide range of imagination and variety. Thus, role playing can enhance the speaking skills of learners in any situation, and it certainly can support students to interact. For the timid learners, role-playing also can helps them by providing masks, whereby learners with conversation difficulties are freed. Above all, it's fun and most learners will completely agree that fun leads to better learning. $20 \%$ of respondents responded "disagree" with the statement that role play motivates students. They had frustration in memorizing English vocabulary so it is very confusing to play it. This can be viewed from the results of the following questionnaire:

"I am less motivated because English words are difficult to memorize, and feel shy to speak because I'm easy to forget vocabulary". (S-4)

Students agree that role playing activities improve their English language skills. It can be seen from these data that $91 \%$ of the total respondents (36 students) agree that role play improve their English ability. Through role playing activities, their knowledge is also enhanced. 93\% of respondents agree that their knowledge of English and the roles they play has improved. This can also be seen from the results of the questionnaire whether there is an enhancement in their English skills. 
Prosiding The 1st National Conference on Applied Business, Education, \& Technology (NCABET)"

Unversitas Bina Bangsa 2021

DOI Article : 10.46306/ncabet.v1i1.34

"There, one of them is an increase in the ability to speak in English, I enjoy my role, I like to learn and memorize new vocabularies and I am very excited to show off my ability in front of class" (S-1).

"Indeed, it really improves my English skills after receiving these lessons, I finally become courageous to speak after trying to adapt with the play many times" (S-2).

Role-playing activities can enhance students' speaking skills in any situation and help them to communicate. Role-playing puts students in a situation whereby they are required to implement and develop forms of language which are essential in oiling social relations works. Students should prepare as well for everything related to their role in English. It is helpful for them to attempt and experiment with the language they require in a friendly and safe classroom environment. Role-playing activities helps and support many timid students by giving them masks so that they become courageous to perform their role.

Role play provides students with new expressions and vocabulary. The questionnaire data shows that $77 \%$ of respondents (31 students) agree that they acquire new vocabulary after doing role-playing activities. Because this activity is a script role play, students need to know the meaning of each written expression. Knowing the meaning of each expression and vocabulary will allow students to play the role and have conversations with ease. It can be seen from the results of the interview whether they learn new vocabulary and expressions.

"Yes. I got a lot of new vocabulary especially in business terms that I had never heard before. So I looked for the meaning first before practicing so that I can easily practice the conversation, it is really helpful and can increase my speaking ability as well "( $S-3)$.

Role-playing develops students' speaking fluency. A wide variety of language functions, e.g. apologizing, greeting, etc., are used more than any other activities. The focus of learners is put on the communication of meaning rather than on the use of appropriate language. Therefore, through role-playing the teacher can practice speaking skills of students in any social situation. It means that students are put in conditions that require speech to be used to communicate socially more than the language required by the teaching syllabus.

Role-playing can help those timid students to deal with their shyness. $66 \%$ of respondents responded "disagree" that they feel embarrassed to show off their role. It means that the students mostly feel free and enjoy practicing and showing off their roles. They are not ashamed of it. This is the advantage of role-playing whereby role playing is that the learners are given the opportunity to pretend to be someone else. Such techniques can help timid students to overcome their shyness in speaking an communicating. Timid students often have difficulty 
talking about their experience or about themselves. In the reality that they are someone else makes them feel that their own personality is not engaged. Students can be anyone they like for a short time. Students can take other people's opinions as well. The functional language of scenarios can be activated and practiced through role-playing in imaginary situations. It has beneficial objective to motivate the students' thinking and creativity, allowing students to develop and practice new language and behavioral skills in a setting that is relatively nonthreatening and can create the motivation and engagement and it's very substantial for learning to develop.

b. Implementation of Role Play

In the interactive class, role-playing activity is administered by performing several employee roles at certain companies that they have prepared in advance. There are eight topics in the English for Business class that should be presented by implementing role play. Three of them are practicing Job Interview, Negotiating A Contract, and Giving A Product Presentation. In the topic of Job Interview, students should pretend to interview another for possible employment. They act them out. In presenting Negotiating A Contract, students should act to negotiate with another team to come to final terms for a contract for services or products. And in practicing A Product Presentation, students should present a product to a group of other students for purchase. At a glance, the students' appearance was already good. They can carry out their role well. However, there are some errors that researchers have noticed. They frequently did some errors in grammar and pronunciation. After the students finished performing the play, the lecturer gave comments and responses / feedback which would later be useful for the students to look good or even better.

Table 1. Business Activities Using Role Play

\begin{tabular}{|c|l|l|}
\hline No & \multicolumn{1}{|c|}{ Materials } & \multicolumn{1}{c|}{ Activities } \\
\hline 1 & Job Interview & $\begin{array}{l}\text { A Student should interview another for } \\
\text { possible employment }\end{array}$ \\
\hline 2 & Negotiate A Contract & $\begin{array}{l}\text { One team of students should negotiate } \\
\text { with another team to come to final terms } \\
\text { for a contract for services or products }\end{array}$ \\
\hline 3 & Give A Product Presentation & $\begin{array}{l}\text { Students should present a product to a } \\
\text { group of other students for purchase }\end{array}$ \\
\hline 4 & Complaining about Services & $\begin{array}{l}\text { One students should express their } \\
\text { dissatisfaction with another "company" } \\
\text { for how they completed a task }\end{array}$ \\
\hline 5 & Ask for Additional Resources & $\begin{array}{l}\text { One Students should talk to his or her } \\
\text { supervisor and convince that person to }\end{array}$ \\
\hline
\end{tabular}




\begin{tabular}{|c|l|l|}
\hline & Delegating Task & $\begin{array}{l}\text { give them more resources, either financial } \\
\text { or people power }\end{array}$ \\
\hline 6 & $\begin{array}{l}\text { A group of students should work together } \\
\text { to list necessary tasks for a project, and } \\
\text { have one person delegate those tasks to his } \\
\text { or her team }\end{array}$ \\
\hline 7 & Recruit Possible Employees & $\begin{array}{l}\text { One student should play a recruiter at a job } \\
\text { fair, or have a mock job fair in the } \\
\text { classroom where half the class is recruiters } \\
\text { and half of the class is potential employees }\end{array}$ \\
\hline 8 & Budget Presentation & $\begin{array}{l}\text { One student should present a budget to his } \\
\text { colleagues for approval }\end{array}$ \\
\hline
\end{tabular}

Essentially students are contented with their performance in role-playing activities. The data from the questionnaire stated that $77 \%$ of respondents were content with their performance. They carry out conversations and act as if they are someone they were playing. Putting students in pairs for dialogue is a simple way to organize even large classes. Dialogue, which involves some kind of action or movement, is the dialogue that works best with students. Intonation is also very important, and students enjoy playing with it. Students pretend to be in various social contexts and have various social roles. In role-playing activities, the teacher provides information to students such as who they are and what they think or feel. Thus, the teacher can tell the student, "You are John; you went to the manager and told him what happened this morning." In role playing, students pretend to be someone else such as a customer, shop assistant, secretary, manager, director, or an owner of a company, etc. "One way to get students to speak in different social contexts and to take on many types of social roles are to implement role-playing activities in the classroom.

Role-playing activity can be administered from a prepared script, design from a set of prompts and expressions or written using and consolidated knowledge obtained from instructions or discussion about speech acts and its modification before the role play itself.

\section{CONCLUSION}

Role-playing is regarded as an effective and appropriate technique to be implemented for teaching English for business. This technique is very effective to trigger and stimulate students' motivation to learn English actively. Students are very excited and they enjoy the learning process through such interesting and interactive activity because they can play someone else's role. Most of the students think that role- playing activities can promote their English ability. Through the preparation of the previous script performs the plays, students 
inevitably learn the vocabulary employ for the play. Then they are recognized vocabulary that they have never known before. In general, respondents showed a positive attitude towards role playing techniques. Only a few students feel embarrassed and timid to appear in front of the class. The implementation of role-playing activities in the class was done successfully. Nevertheless, there were some mistakes in applying grammar and pronunciation. Criticism, evaluation and comments from lecturers should be provided to make students show off the best.

\section{THANK-YOU NOTE}

Deep gratitude to the Rector of University of Bina Bangsa, Dr. H. Furtasan Ali Yusuf, SE., S.Kom., MM and also all lecturers of University of Bina Bangsa.

\section{REFERENCES}

Gordon, E., Haas, J., \& Michelson, B. (2017). Civic creativity: Role-playing games in deliberative process. International Journal of Communication.

Grande-de-Prado, M., Baelo, R., García-Martín, S., \& Abella-García, V. (2020). Mapping roleplaying games in Ibero-America: An educational review. In Sustainability (Switzerland). https://doi.org/10.3390/SU12166298

Harmer, J. (2001). The Practice of English Language Teaching Third Edition. ELT Journal.

Iskandar, A., \& Saragih, R. (2018). the Influence of Attitude Toward the Behavior, Subjective Norms, and Perceived Behavioral Control on Whistle-Blowing Intention and Behavior of CPNS. Journal of Finance and Accounting.

Krebt, D. M. (2017). The effectiveness of role play techniques in teaching speaking for efl college students. Journal of Language Teaching and Research. https://doi.org/10.17507/jltr.0805.04

Kumaran, S. R. (2017). Benefits and Shortcomings of Role-Play As a Speaking Activity in English Language Classrooms. The English Teacher.

Kustiarini, K.--, \& Prasetyo, P.-. (2018). PENINGKATAN HASIL BELAJAR MATEMATIKA MELALUI METODE ROLE PLAYING BAGI SISWA KELAS IV SD. DIKDAS MATAPPA: Jurnal Ilmu Pendidikan Dasar. https://doi.org/10.31100/dikdas.v1i1.213

Moreno-Guerrero, A. J., Rodríguez-Jiménez, C., Gómez-García, G., \& Navas-Parejo, M. R. (2020). Educational innovation in higher education: Use of role playing and educational video in future teachers' training. Sustainability (Switzerland). https://doi.org/10.3390/su12062558

Perloff, R. (2017). Attitudes: Definition and Structure. The Dynamics of Persuasion: Communication and Attitudes in the 21st Century.

Samalot-Rivera, A. (2014). Role Playing in Physical Education to Teach in the Affective Domain. Journal of Physical Education, Recreation \& Dance. https://doi.org/10.1080/07303084.2014.866834

Zagal, J. P., \& Deterding, S. (2019). Definitions of "Role-Playing Games." In Role-Playing Game Studies. https://doi.org/10.4324/9781315637532-2 